\title{
A longitudinal analysis of corporate greenhouse gas disclosure strategy
}

Article

Accepted Version

Liu, Y. S. and Yang, J. (2018) A longitudinal analysis of corporate greenhouse gas disclosure strategy. Corporate Governance: The International Journal of Business in Society, 18 (2). pp. 317-330. ISSN 1472-0701 doi:

https://doi.org/10.1108/CG-11-2016-0213 Available at https://centaur.reading.ac.uk/69503/

It is advisable to refer to the publisher's version if you intend to cite from the work. See Guidance on citing.

To link to this article DOI: http://dx.doi.org/10.1108/CG-11-2016-0213

Publisher: Emerald

All outputs in CentAUR are protected by Intellectual Property Rights law, including copyright law. Copyright and IPR is retained by the creators or other copyright holders. Terms and conditions for use of this material are defined in the End User Agreement.

\section{www.reading.ac.uk/centaur}

\section{CentAUR}

Central Archive at the University of Reading 
Reading's research outputs online 


\section{A Longitudinal Analysis of Corporate Greenhouse Gas Disclosure Strategy}

Yang Stephanie Liu and Jessica Hong Yang*

Henley Business School, University of Reading, Whiteknights, Reading RG6 6UD, UK

*Corresponding author. Tel: +44 (0) 118378 6444. Email: j.h.yang@henley.ac.uk

Co-author email: stephanie.liu@henley.ac.uk 


\title{
A Longitudinal Analysis of Corporate Greenhouse Gas Disclosure Strategy
}

\author{
Yang Stephanie Liu and Jessica Hong Yang ${ }^{*}$
}

Henley Business School, University of Reading, Whiteknights, Reading RG6 6UD, UK

*Corresponding author. Tel: +44 (0) 118378 6444. Email: j.h.yang@henley.ac.uk

Co-author email: stephanie.liu@henley.ac.uk

\section{A Longitudinal Analysis of Corporate Greenhouse Gas Disclosure Strategy}

\begin{abstract}
Purpose

This paper aims to investigate the extent to which greenhouse gas (GHG) -sensitive companies in the FTSE 100 disclose carbon emission information in their annual reports and standalone reports during the period of 2004-2012, and how they respond to the launch of legally binding GHG reduction schemes - the EU Emission Trading Scheme (EU ETS) and the Climate Change Act (CCA).
\end{abstract}

\section{Design/methodology/approach}

A 42-item disclosure index is constructed to analyse the quality of corporate GHG disclosures. We initially chart the development of corporate GHG disclosure from 2004 to 2012, analyse the trend of disclosure development and compare variances for the convergence of disclosures. Subsequently we carry out a t-test to assess the significance of post-EU ETS and -CCA changes and the difference between GHG trading account holders and non-account holders.

\section{Findings}

The results show that GHG disclosures have been increasing over time, both in number of firms making disclosures and in the amount of information being reported, which indicates the movement towards normativity. We also find that the disclosures reach the peak after the enactment of EU ETS and CCA, and firms with carbon trading accounts are more responsive to these schemes than those without accounts. Nevertheless, the quality of the disclosure remains low, which may justify the further government intervention of mandating carbon reporting.

\section{Originality/value}


This is the first paper that has examined the regulatory effects on GHG disclosures in an environment where GHG emission triggers direct cost for companies.

Key words: GHG disclosures, GHG emissions, institutional legitimacy theory, strategic legitimacy theory, content analysis

Paper type: Research paper 


\section{Introduction}

This paper aims to offer a longitudinal investigation on the quality of greenhouse gas (GHG) disclosures of the 25 largest, publicly listed UK companies in the utility, mining and energy industries over a nine-year period from 2004 to 2012. In 2005, the European Emission Trading Scheme (EU ETS) was launched to support the EU-wide goal of reducing GHG emissions to the level required by the Kyoto Protocol (European Commission, 2015). The EU ETS mandates emission accounting and trading for companies operating in Europe in particular sectors, and it requires participants to develop new knowledge and advantages within the company (Engels, 2009) and to learn to deal with disclosure and reporting issues. The Climate Change Act (CCA) was then enacted in 2008 and established a legally binding framework to develop an economically credible emission reduction path. These new schemes, coupled with voluntary guidelines - such as Carbon Disclosure Project (CDP), Global Reporting Initiatives (GRI), World Business Council for Sustainable Development and World Resources Institute (WBCSD\&WRI) and Department for Environment Food and Rural Affairs (DEFRA) - create high levels of uncertainty on the reporting and disclosure of GHG and a need for a longitudinal study on the development of GHG disclosures.

This paper draws from the institutional and strategic legitimacy theories (DiMaggio \& Powell, 1983; Dowling \& Pfeffer, 1975), which argue that the social and institutional context in which an organization operates determines the legitimization of the organization and its access to operational resources (Campbell, 2004; Cho \& Patten, 2007; Cormier, Magnan, \& Van Velthoven, 2005; Patten, 1992). By using a self-constructed index, we seek to examine the motivations of the companies to increase GHG disclosures over time. More precisely, we analyse how companies responded to the EU ETS and CCA during this period. In line with institutional legitimacy theory, our results show that the disclosures have been increasing over time, both in number of companies making disclosures and in the amount of information being reported. There is significant imitation of disclosures among companies within similar GHG exposure groups. We also find that there is a significant increase of GHG disclosure after the launch of the EU ETS and CCA, and companies with GHG trading accounts are more responsive to the schemes than those without the accounts. This result is in line with strategic legitimacy theory, which states that companies with more social exposure and pressure tend to disclose more (Gray, Kouhy, \& Lavers, 1995; Mahadeo, Oogarah-Hanuman, $\&$ Soobaroyen, 2011). Nevertheless, the quality of the disclosure still remains low, which 
may explain the incentive of the UK government to have introduced, in 2013, mandatory GHG reporting under the Companies Act 2006.

This paper contributes to the literature in several ways. First, to our knowledge, no prior study has examined the regulatory effects on GHG disclosures in an environment where GHG emission triggers direct costs for companies. Extant literature suggests a positive impact of voluntary GHG reporting guidance by DERFA on corporate GHG disclosures (Tauringana \& Chithambo, 2014) and improved transparency and convergence of GHG disclosures after the participation of the CDP (Matisoff, Noonan, \& O'Brien, 2013). However, the corporate motivation of GHG disclosures and the efficacy of the mandatory GHG management schemes are still unknown. Second, instead of using CDP data (Matisoff et al., 2013; Stanny, 2013) as proxy for GHG disclosure, we develop a disclosure index consisting of 42 items and investigate the disclosures in corporate annual and stand-alone reports, which represent the source of information that various sectors of the community rely upon (Deegan, Rankin, \& Voght, 2000).

The remainder of this paper is organized as follows. The next section reviews the literature and develops hypotheses in relation to legitimacy theory. Section 3 outlines the research methodology, which relies on the content analysis method of data collection. Section 4 presents the results, and in Sections 5 and 6 we present a discussion of the data and a conclusion.

\section{Literature review and hypothesis development}

Legitimacy theory has been widely used to explain the motivation of corporate social and environmental disclosure (Deegan, Rankin, \& Tobin, 2002; O’Donovan, 2002; Patten, 1992) based on the concept of social contract between an organization and the society in which it operates (Pellegrino \& Lodhia, 2012). The organization makes voluntary disclosure to gain or maintain legitimacy with relevant stakeholders or publics (Dowling \& Pfeffer, 1975). In the test of explanatory power of legitimacy theory, institutional legitimacy explains why companies behave in a particular way (Hall, 1977), while strategic legitimacy predicts companies' behaviour in a given period (Cormier et al., 2005). 


\subsection{Institutional legitimacy and relevant CSR disclosure evidence}

Institutional legitimacy theory offers a complementary theoretical perspective to explain corporate social and environmental disclosures. It is concerned with the relationship between an organization and its environments and recognizes the influence of environment on organizational structure and processes (DiMaggio \& Powell, 1983; Scott, Ruef, Mendel, \& Caronna, 2000; Zucker, 1977). Instead of achieving organizational efficiency, institutional legitimacy theory is based on the premise that organizations should incorporate social and institutional beliefs in order to maintain their stability and legitimacy in society (DiMaggio \& Powell, 1983; Meyer \& Rowan, 1977). The incentive of being efficient is insufficient to explain why organizations are becoming homogeneous. Scott et al. (2000) adds that material resources and technical information are not enough for organizations to survive and compete in their social environments. As a result, organizations do not always rationalize decisions, but often take a lead from industry peers who have dealt with a similar situation, and follow a set of pre-existing institutionalized options (Oliveira, Junior, \& Oliveira, 2014).

The concept of institutional isomorphism indicates that organizations must take into account other organizations' behaviour (Aldrich, 1979), which forms the institutional context of the organization in the long run and drives the organization to behave in similar ways as those other organizations do. An institution is thus formed when comparisons and imitations are made, based on an individual organization's perception of its environment. The pattern of the established institutions is viewed as the symbolic representation of the social value system through the lens of institutional legitimacy theory (Chen \& Roberts, 2010), and environmental disclosure, it is argued, becomes institutionalized over time as structures and practices that symbolize the stakeholder concern of corporate environmental issues (Scott et al., 2000).

There are a limited number of studies investigating the convergence of corporate social responsibility (CSR) disclosure. For example, Cormier et al. (2005) analyse the CSR disclosure quality of 70 non-financial German companies during the period 1992-1998 and find evidence that these companies have imitation tendencies and adopt a routine approach as they extend their prior period's CSR disclosures. Kim and Lyon (2011) compare the social disclosure of 30 matched Australian and South African mining companies, and both demonstrate the legitimization offered by isomorphism and evidence the institutionalization of CSR disclosure in these two countries. Matisoff et al. (2013) examine the trends relating to 
GHG disclosure, and report on the extent to which companies have increased transparency over time with a focus on Scope 2 and Scope 3 emissions. Their content analysis of corporate CDP responses from 2003 to 2010 has exhibited convergence in corporate GHG reporting in CDP over time. We therefore posit:

\section{Hypothesis 1. There is a convergence of corporate GHG disclosures in the annual} reports and stand-alone reports over time.

\subsection{Strategic legitimacy and relevant CSR disclosure evidence}

The strategic view of legitimacy theory considers the acquisition of legitimacy as a strategic resource for the survival of an organization (Mohamed, Sylvain, \& Jacques, 2014). To gain or maintain legitimacy, organizations need to consider the political environment in which they operate. Strategic legitimacy is directly linked with political economy theory from this point of view. Since the expectations from the society change over time (Deegan, 2002), legitimacy is a dynamic process. Organizations must change their policies and performance so as to be perceived legitimate to operate within social bounds and norms, and to guarantee their access to the operational resources (Dowling \& Pfeffer, 1975; Pellegrino \& Lodhia, 2012). A legitimacy threat or gap is formed as a result of changes in social awareness, pressures from regulatory or institutional sources, the media or stakeholder groups, and corporate crises (Mohamed et al., 2014; O’Donovan, 2002). CSR disclosure is therefore regarded by prior literature (Cho \& Patten, 2007; Deegan et al., 2002; Dowling \& Pfeffer, 1975; Mahadeo et al., 2011; Patten, 1992; Wiseman, 1982) as the main corporate communication media to address the threats to legitimacy when companies are subject to social exposure and need to disclose relevant information to preserve their legitimacy with their relevant stakeholders.

Testing the explanatory power of strategic legitimacy theory relies on the matching of 'peak disclosure periods with periods of significant social, economic or political events affecting the company' (Guthrie \& Parker, 1989, p.351). Empirical studies yield mixed results (Cho \& Patten, 2007; Deegan et al., 2002; Dowling \& Pfeffer, 1975; Mahadeo et al., 2011; O’Donovan, 2002). For instance, Guthrie and Parker (1989) investigate the 100-year social disclosures from an Australian mining company, BHP, but do not find the match between the peak of social disclosures and social events, and, therefore, they fail to conclude the primary explanatory power of strategic legitimacy theory of social disclosures. Patten (1992) conducts a study of the impact of the Exxon Valdez oil spill on corporate social disclosures of 
petroleum companies other than Exxon and finds a significant increase in disclosures, which is in support of the explanatory power of strategic legitimacy theory. More recent studies of social disclosures notice the decrease of social disclosures in recent years and try to explain this through the lens of legitimacy theory. De Villiers and Van Staden (2006) argue that organizations will adjust the extent (upwards or downwards) and the type (general or specific) of social and environmental disclosures to meet the changing needs of social expectations and keep their legitimacy. Their study contributes to strategic legitimacy theory by adding this new dimension of reducing social disclosures as a legitimizing strategy. This also leads to the reconsideration of the previous mixed results; increased social expectation in one specific issue leads to increased disclosure in that issue and decreased disclosure in other social and environmental areas. The overall trend of CSR disclosure is therefore uncertain. Furthermore, the perceived change of expectation is a rather subjective issue to measure and to compare between different organizations, even between organizations from the same industry in the same country. We argue that the increase of perceived expectation is easier to observe than the decrease of expectation, as increased expectation could be evidenced from specific social agendas and events, while the decrease of social expectation is more 'invisible'.

Investigating corporate GHG disclosure alone eliminates the above problem. As one individual aspect of corporate environmental issues, it is more straightforward to decide that there is increased social expectation from society, with the introduction of GHG management schemes. This leads to our second hypothesis:

Hypothesis 2. The improvement of GHG disclosures quality is higher post EU ETS 2005 and CCA 2008.

Strategic legitimacy theorists argue that CSR disclosures are driven by public pressure. Companies from socially and environmentally sensitive industries are therefore exposed to more pressure and will engage in more social and environmental disclosures than those in less sensitive industries. Empirical studies find a positive association between operating industry and CSR disclosure (Deegan \& Gordon, 1996; Peng, Sun, \& Luo, 2015), while other studies do not find any significant difference in the disclosures among companies from different industries (Mahadeo et al., 2011). We argue that the mixed results could be caused by the same reason above: industries might respond differently to different social and environmental threats. Membership of lobby groups is another essential legitimacy-based 
variable (Chauvey, Giordano-Spring, Cho, \& Patten, 2015). There is a positive association between industry membership and organizational CSR disclosure found in previous literature (Campbell, 2004; Chauvey et al., 2015; Deegan \& Gordon, 1996). In terms of climate change, we further argue that companies with a GHG trading account are more GHGemission sensitive, and thus are more willing to make GHG disclosure to the public to demonstrate their legitimacy in their operations (Dowling \& Pfeffer, 1975). Hence our next hypotheses are as follows:

Hypothesis 3. GHG trading account holders are more likely to make better quality GHG disclosures than non-account holders.

Hypothesis 4. GHG trading account holders are expected to make better quality GHG disclosures than non-account holders after the introduction of EU ETS and CCA.

\section{Method}

We use data drawn from 306 annual and standalone reports published by 25 FTSE 100 companies (based on the 2012 FTSE 100 list) in the utility, mining and energy industries, which are deemed to be the top three industries for GHG emissions (CDP, 2012), over the period 2004-2012. This sample group is designed to represent companies most exposed to GHG emission regulations, guidelines and public pressure. The sample selected provides a unique setting in which to investigate the issues raised for three reasons. First, in the study period, EU ETS was launched to mandate emission accounting and trading for companies operating in Europe in particular sectors, and requires participants to develop new knowledge and advantages within the company (Engels, 2009). The CCA, enacted in 2008, established a legally binding framework to develop an economically credible emission reduction path. Second, we are able to split the study period into four distinct periods - pre- and post- both EU ETS and CCA - which enables us to capture the effects of these schemes. Third, the selection of GHG-sensitive industries provides us with an opportunity to examine the extent to which the GHG disclosures have been gradually improved in response to the guidance and regulations. As an emerging topic, GHG emission disclosures are inconsistent, even by the largest international companies (Freedman \& Jaggi, 2005); selecting the most GHG-sensitive industries enables sufficient data for trend and statistical analysis. 
The sample comprises 12 GHG trading account holders and 13 non-GHG trading account holders, using the European Commission database of European Union Transaction $\log ^{1}$. In the transaction log we use the database of Operator Holding Accounts. Account holder means a person who holds an account in the registries system.

Deegan (2002) indicates that financial report disclosures are used by the management of companies as a legitimizing tool, and the annual report is the most important media for companies to communication to their stakeholders and the public (Adams, Hill, \& Roberts, 1998). Information disclosed in annual reports are widely used in previous research (Cho \& Patten, 2007; Mahadeo et al., 2011; Patten, 1992; Wiseman, 1982). In addition to annual reports, we also use CSR and/or standalone reports to examine the quality of corporate GHG disclosures. We do this for the following reasons. First, GHG reporting is more technical than other social and environmental issues; companies prefer to provide more detailed GHG information in their standalone reports rather than their annual reports. Second, while the social and environmental information in annual reports is not usually audited, the existence of more and more standalone reports enhances the credibility and quality of the information disclosed.

The annual reports and standalone reports are downloaded from companies' websites. The final sample comprises 207 firm-year observations and 306 corporate annual and standalone reports.

\subsection{Measures}

To measure corporate GHG disclosure, existing literature mainly uses the CDP data either as the proxy for the existence of GHG disclosure of companies and/or as proxy for the quality of GHG disclosure (Kolk, Levy, \& Pinkse, 2008; Liao, Luo, \& Tang, 2014; Stanny, 2013). CDP change their questionnaire over time and the company's response is also in a state of constant change (Kolk et al., 2008; Liao et al., 2014). Using CDP data is therefore not suitable for this longitudinal analysis and comparison. Another data source of existing GHG disclosure literature is content analysis of annual reports and/or CSR reports, which is more discretionary than corporate response to the CDP questionnaire (Freedman \& Jaggi, 2005; Peng et al., 2015). For the purpose of this study, qualitative content analysis is more appropriate to assess the quality of corporate GHG disclosure than the quantity of disclosures

\footnotetext{
${ }^{1}$ See http://ec.europa.eu/environment/ets/welcome.do?languageCode=en
} 
(Mohamed et al., 2014; Wiseman, 1982). This paper extends prior studies by using a selfconstructed 42-item disclosure index under three main themes: Engagement and Strategy, Performance and Measurements, and Risks and Opportunities. Besides the extant environmental disclosure and GHG emission studies, the index design closely follows certain GHG accounting and reporting guidelines, which include: GRI, WBCSD\&WRI, DEFRA, CDP and GHG accounting and reporting literature (Cook, 2009; Hopwood, 2009; Kolk et al., 2008; Lohmann, 2009), and also the research associations of corporate GHG emission accounting and reporting issues.

A score of ' 1 ' is awarded for each item in the index when the information is disclosed in either annual reports or standalone reports; a score of ' 0 ' is otherwise given. The total score thus ranges from 0 to 42 .

We initially chart the development of corporate GHG disclosure from 2004 to 2012 and analyse the trend of disclosure development, and compare the variances for the convergence of disclosures (Cormier et al., 2005). We subsequently carry out a t-test (Cho \& Patten, 2007; Mahadeo et al., 2011) to assess the significance of post-EU ETS and -CCA changes and the difference between GHG trading account holders and non-account holders.

\section{Results}

\subsection{Descriptive statistics}

Descriptive data are provided in

Table 1. There are fewer observations for the years 2004, 2005 and 2006 as the annual reports and/or standalone reports are not available from the companies' websites. This gives rise to an unbalanced panel dataset with 207 firm-year observations. From the results, it is clear that there is an upward trend of corporate GHG disclosure since 2004. The mean score increases from 9.37 in 2004 to 20.04 in 2012, which represents a $113.9 \%$ increase and a significant improvement of corporate GHG disclosure in the last nine years. If compared with the maximum score of 42 that a company could get, the level of disclosure is still at a relatively low level. Until 2011, there are companies that do not make any GHG or climate change disclosures and so have a score of zero in 2011. The results are in line with extant literature that corporate GHG disclosure is still in its infancy and lacks consistency (Freedman \& Jaggi, 
2005). The standard deviation declines by $20.9 \%$ from 2004 to 2012 , indicating that GHG disclosures among companies are characterized by a reduced degree of variety and an increasing convergence over time. The coefficient of variation is also significantly reduced by $63 \%$, from 1.046 to 0.387 during the time period, which indicates that the disclosure quality is much less dispersed in year 2012. These results support Hypothesis 1, thus suggesting that imitation is taking place among companies over time.

Table 1 Summary statistics of sample disclosures

\begin{tabular}{cccccccc} 
Year & N & Minimum & Maximum & Sum & Mean & $\begin{array}{c}\text { Std. } \\
\text { deviation }\end{array} \begin{array}{c}\text { Coefficient } \\
\text { of variation }\end{array}$ \\
\hline Y2004 & 19 & 0 & 27 & 178 & 9.37 & 9.805 & 1.046 \\
Y2005 & 20 & 0 & 29 & 197 & 9.85 & 10.127 & 1.028 \\
Y2006 & 21 & 0 & 29 & 261 & 12.429 & 10.142 & 0.816 \\
Y2007 & 22 & 0 & 34 & 326 & 14.818 & 10.883 & 0.734 \\
Y2008 & 25 & 0 & 35 & 380 & 15.20 & 11.064 & 0.728 \\
Y2009 & 25 & 0 & 33 & 414 & 16.56 & 10.572 & 0.638 \\
Y2010 & 25 & 1 & 35 & 455 & 18.20 & 9.622 & 0.529 \\
Y2011 & 25 & 0 & 33 & 498 & 19.92 & 8.573 & 0.430 \\
Y2012 & 25 & 6 & 33 & 501 & 20.04 & 7.759 & 0.387 \\
Total & 207 & & & & & & \\
\hline
\end{tabular}

A time evolution comparison between quantitative and qualitative disclosure is presented in Figure 1. The percentage is calculated by the actual disclosure score as a percentage of the maximum score of this type of disclosure. Two almost parallel lines can be seen in the figure, which indicates that companies improve their quantitative and qualitative disclosures at generally the same time, and companies do not increase any types of disclosure specifically after the launch of EU ETS and CCA. However, an overall preference for qualitative disclosure can be noticed. Companies only meet $15 \%$ of expected quantitative GHG disclosure in 2004 while meeting almost $30 \%$ of expected qualitative disclosures. In 2012, these figures have increased to approximately $35 \%$ and $55 \%$ respectively. The quantitative disclosure is yet to be satisfactory, with less than half of the expectations.

From the analysis above, there is an overall improvement of corporate GHG disclosures during the period 2004-2012. It is, however, not obvious to see the yearly change of the disclosures from these figures. Therefore further investigation is conducted using t-tests to examine whether corporate GHG disclosures change significantly after the launch of GHG trading and reduction schemes. 


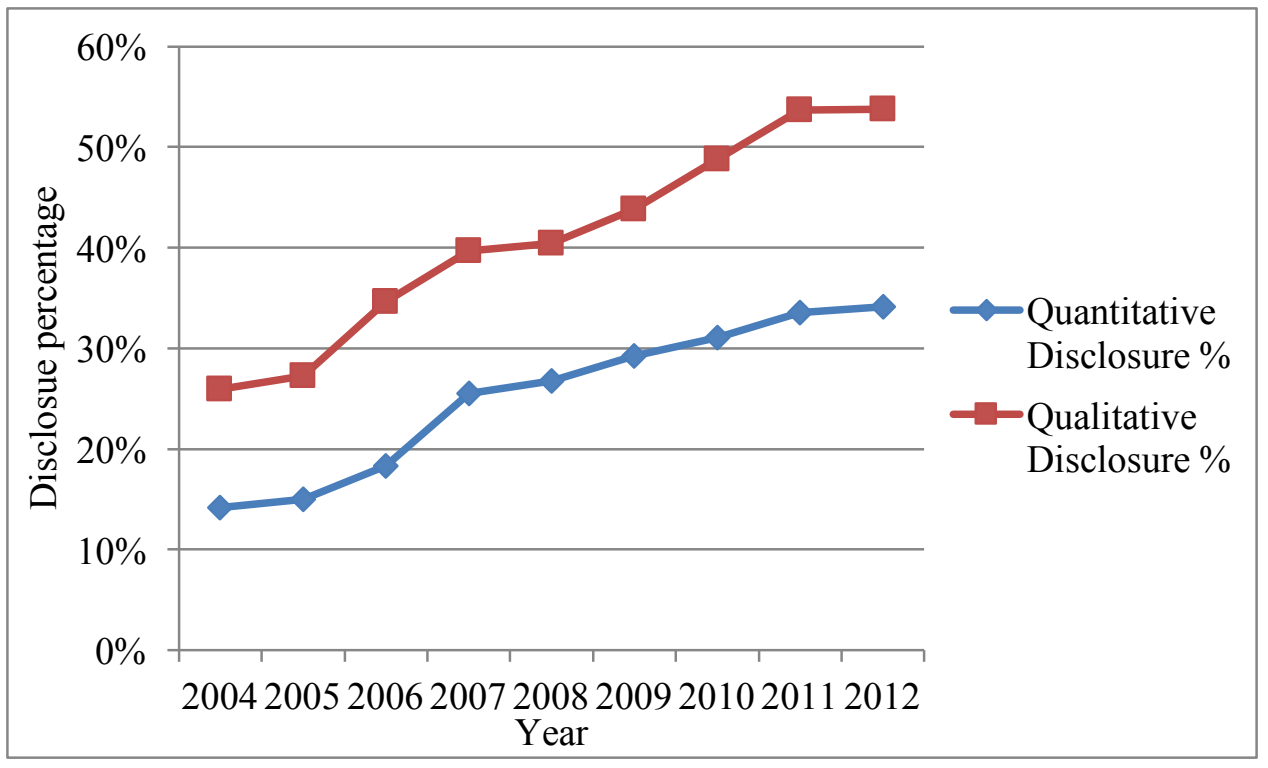

Figure 1 Percentage of quantitative and qualitative disclosures made by sample companies from 2004 to 2012

\subsection{T-test for yearly disclosure change}

A paired samples t-test is used to test the hypothesis of equality of variances and to identify if there is statistical significance of corporate disclosure change during the period 2004-2012. In this case, t-tests are conducted for each contiguous two-year group (e.g. the disclosure scores of 2004 and 2005, the disclosure scores of 2005 and 2006, etc). The results of paired sample t-tests of sample companies' yearly GHG disclosures are presented in

Table 2. As highlighted in the table, the means of variance of each pair sample are all less than zero, indicating that the disclosure scores in later years are higher. The mean disclosure score of 2006 is 2.55 higher than that of 2005 , where p-value equals 0.003 , which is statistically significant at 0.05 level. The differences of pair 3 (year 2006 and year 2007), pair 5 (year 2008 and year 2009), and pair 6 (year 2009 and year 2010) are all statistically significant ( $\mathrm{p}<0.05$, two-tailed), which means corporate GHG disclosures significantly improved after the launch of EU ETS 2005 and CCA 2008, and the impact of the schemes last for one more year after the schemes have been introduced. For the rest of the paired samples, p-values are greater than 0.05 - therefore the variances are not significant, which is in support of Hypothesis 2.

The t-test relies on a number of assumptions as it is a parametric test. In this case, as the sample size is relatively small, a normality test is not as reliable as for a large sample. Wilcoxon matched-paired tests are conducted using IBM SPSS Statistics 21 and the results 
are essentially equivalent to the results of the parametric tests. This method is used in extant literature for the reliability of the results (Cho \& Patten, 2007; Mahadeo et al., 2011).

Furthermore, it is also found that the standard deviations significantly increase after the enactment of EU ETS 2005 and CCA 2008, which is consistent with Mahadeo et al. (2011) study, which finds that there is a significant increase in the variety of CSR disclosures in annual reports in response to the enactment of Code of Corporate Governance and in order to satisfy the multiplicity of social expectations. It provides further evidence in support of Hypothesis 2.

Table 2 Results of paired samples t-tests of yearly disclosures

\begin{tabular}{|c|c|c|c|c|c|c|c|c|c|}
\hline & & \multicolumn{5}{|c|}{ Paired differences } & \multirow[t]{3}{*}{$\mathrm{t}$} & \multirow[t]{3}{*}{$\mathrm{df}$} & \multirow{3}{*}{$\begin{array}{l}\text { Sig. (2- } \\
\text { tailed) }\end{array}$} \\
\hline & & \multirow[t]{2}{*}{ Mean } & \multirow[t]{2}{*}{$\begin{array}{c}\text { Std. } \\
\text { deviation }\end{array}$} & \multirow[t]{2}{*}{$\begin{array}{l}\text { Std. } \\
\text { error } \\
\text { mean }\end{array}$} & \multicolumn{2}{|c|}{$\begin{array}{l}95 \% \text { Confidence } \\
\text { interval of the } \\
\text { difference }\end{array}$} & & & \\
\hline & & & & & Lower & Upper & & & \\
\hline Pair 1 & $\begin{array}{l}\text { score2004- } \\
\text { score2005 }\end{array}$ & -1.00000 & 2.78887 & .63981 & -2.34419 & .34419 & -1.563 & 18 & .135 \\
\hline Pair 2 & $\begin{array}{l}\text { score } 2005- \\
\text { score } 2006\end{array}$ & -2.55000 & 3.36350 & .75210 & -4.12417 & -.97583 & -3.390 & 19 & .003 \\
\hline Pair 3 & $\begin{array}{l}\text { score2006- } \\
\text { score2007 }\end{array}$ & -2.95238 & 3.78783 & .82657 & -4.67658 & -1.22818 & -3.572 & 20 & .002 \\
\hline Pair 4 & $\begin{array}{l}\text { score } 2007- \\
\text { score } 2008\end{array}$ & -1.00000 & 3.19225 & .68059 & -2.41537 & .41537 & -1.469 & 21 & .157 \\
\hline Pair 5 & $\begin{array}{l}\text { score } 2008- \\
\text { score } 2009\end{array}$ & -1.36000 & 3.21299 & .64260 & -2.68626 & -.03374 & -2.116 & 24 & .045 \\
\hline Pair 6 & $\begin{array}{l}\text { score2009- } \\
\text { score2010 }\end{array}$ & -1.64000 & 3.83927 & .76785 & -3.22477 & -.05523 & -2.136 & 24 & .043 \\
\hline Pair 7 & $\begin{array}{l}\text { score } 2010- \\
\text { score } 2011\end{array}$ & -1.72000 & 4.17852 & .83570 & -3.44481 & .00481 & -2.058 & 24 & .051 \\
\hline Pair 8 & $\begin{array}{l}\text { score2011- } \\
\text { score } 2012\end{array}$ & -.12000 & 4.64866 & .92973 & -2.03887 & 1.79887 & -.129 & 24 & .898 \\
\hline
\end{tabular}

\subsection{Difference in disclosure between account holder and non-account holder}

Table 3 presents the descriptive analysis for GHG disclosures of GHG trading account holders and non-GHG-account holders from 2004 to 2012. GHG disclosures of both account holder companies and non-account holder companies are relatively low in the earlier years. For example, the disclosure score of account holder companies is 14.1 in 2004 while it is only 4.1 for non-account holder companies; the maximum score a company could get is 42 . The disclosures of account holder companies are higher than that of non-account holder companies throughout all the nine years, and the average scores of these two groups developed almost in parallel. One of the criteria for using a parametric t-test is the assumption that both populations have equal variances . In Table 5, all p-values of Levene's test are 
greater than 0.05 , therefore equal variance assumptions are accepted when interpreting the $\mathrm{t}$ test results. All the t-tests results are significant with $\mathrm{p}<0.05$, indicating that the disclosures of GHG trading account holder companies and non-account holder companies are statistically and significantly different. Therefore account holder companies tend to disclose more GHG information than non-account holder companies - Hypothesis 3 is thus supported.

Interestingly, the difference in disclosure between these two groups is decreasing gradually over the years. In 2004, the average disclosure of non-account holder companies is $70.84 \%$ less than account holder companies, while this figure decreases to $30.61 \%$ in 2012 . Furthermore, the yearly disclosure improvement data shows that, in general, non-account holder companies improve their GHG disclosures at a more rapid speed. In terms of reaction to the enactment of EU ETS and CCA, GHG trading account holder companies are more responsive to the introduction of these schemes, with disclosure improvement of 0.09 for account holder and 0.07 for non-account holder companies in 2005, and of 0.05 for account holders and 0.02 for non-account holders in 2008 . These are the only two years when account holder companies improve their GHG disclosure more than non-account holder companies across the time period 2004-2012 ( 
Table 4). The result is in support of Hypothesis 4.

Table 3 Descriptive analysis for account holders (AH) and non-account holders (NAH)

\begin{tabular}{lcccccc} 
& STATUS & N & Mean & Difference \% & Std. deviation & Std. error mean \\
\hline \multirow{2}{*}{ Year2004 } & AH & 10 & 14.1000 & & 9.31486 & 2.94562 \\
& NAH & 9 & 4.1111 & -70.84 & 7.72082 & 2.57361 \\
Year2005 & AH & 10 & 15.3000 & & 9.64999 & 3.05159 \\
& NAH & 10 & 4.4000 & -71.24 & 7.57481 & 2.39537 \\
Year2006 & AH & 11 & 17.1818 & & 9.50598 & 2.86616 \\
& NAH & 10 & 7.2000 & -58.10 & 8.37722 & 2.64911 \\
Year2007 & AH & 11 & 20.3636 & & 7.54020 & 2.27345 \\
& NAH & 11 & 9.2727 & -54.46 & 11.14532 & 3.36044 \\
Year2008 & AH & 12 & 21.4167 & & 8.19599 & 2.36598 \\
& NAH & 13 & 9.4615 & -55.82 & 10.43724 & 2.89477 \\
Year2009 & AH & 12 & 22.2500 & & 8.33530 & 2.40619 \\
& NAH & 13 & 11.3077 & -49.18 & 9.87745 & 2.73951 \\
Year2010 & AH & 12 & 22.4167 & & 9.28790 & 2.68119 \\
& NAH & 13 & 14.3077 & -36.17 & 8.47924 & 2.35172 \\
Year2011 & AH & 12 & 23.8333 & & 6.56206 & 1.89430 \\
& NAH & 13 & 16.3077 & -31.58 & 8.83539 & 2.45050 \\
Year2012 & AH & 12 & 23.8333 & & 7.08177 & 2.04433 \\
& NAH & 13 & 16.5385 & -30.61 & 6.83880 & 1.89674 \\
\hline
\end{tabular}


Table 4 Yearly disclosure improvement rate (IR) for account holders (AH) and non-account holders (NAH)

\begin{tabular}{l|ccccccccc} 
& 2004 & 2005 & 2006 & 2007 & 2008 & 2009 & 2010 & 2011 & 2012 \\
\hline AH IR & N/A & 0.09 & 0.12 & 0.19 & 0.05 & 0.04 & 0.01 & 0.06 & 0.00 \\
NAH IR & N/A & 0.07 & 0.64 & 0.29 & 0.02 & 0.20 & 0.27 & 0.14 & 0.01
\end{tabular}

Table 5 Independent samples t-test of account holders and non-account holders

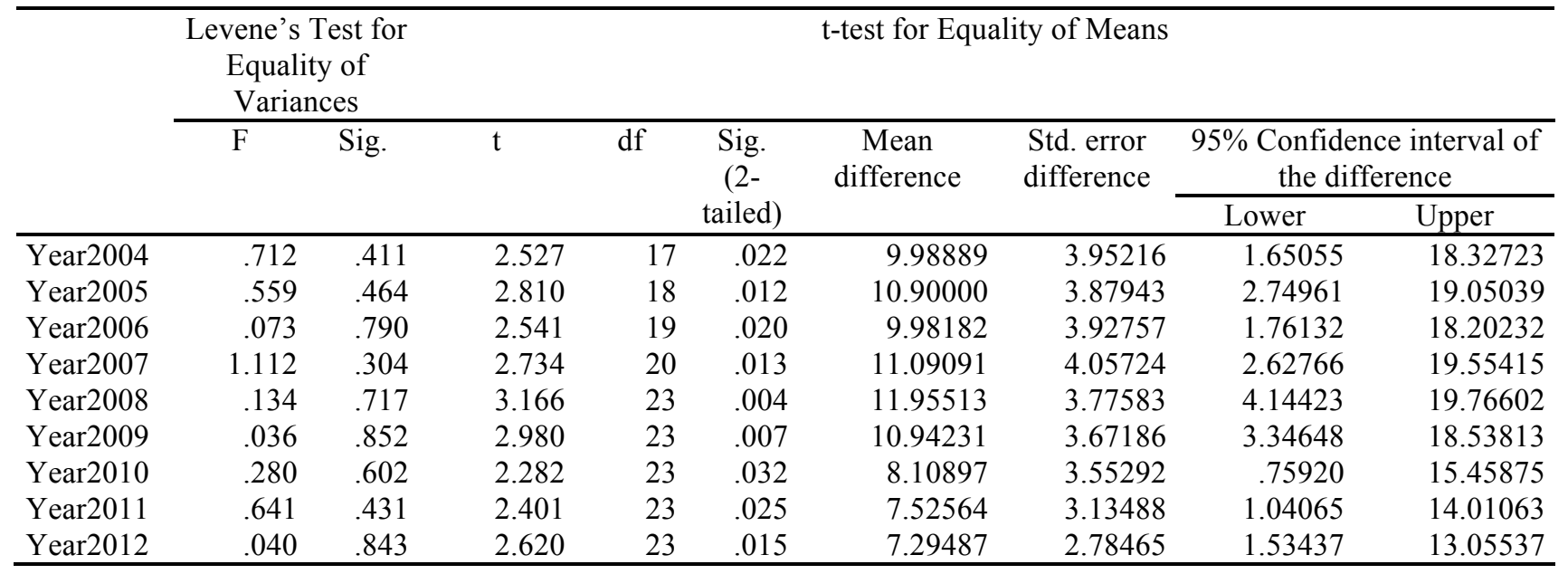

\section{Discussion}

The findings of this study show a significant improvement of corporate GHG disclosures from 2004 to 2012 and a statistically significant increase after the launch of EU ETS and CCA. The introduction of EU ETS and CCA caused increasing expectations regarding how companies conduct business. The disclosure of GHG emission information serves as an instrument for generating favourable impressions of companies and therefore preserving organizational legitimacy. The results are in support of strategic legitimacy theory, which posits that peak disclosure periods match with significant social, economic or political events affecting the companies (Guthrie \& Parker, 1989). Previous studies show mixed results. Some studies find a significant relationship between community concern for particular social and environmental issues and corporate CSR disclosures (Deegan et al., 2002; Gray et al., 1995; Patten, 1992), while other studies fail to confirm legitimacy theory as the primary explanation of corporate CSR disclosure (Guthrie \& Parker, 1989), or suggest that legitimacy could be one of the causes that drive corporate CSR disclosure status (Bebbington, LarrinagaGonzález, \& Moneva-Abadía, 2008; Campbell, 2004). A plausible reason for the mixed results could be that these studies examine the disclosure of a variety of social and environmental issues, as companies will adjust the extent (upwards or downwards) and the 
type (general or specific) of social and environmental disclosures to meet the changing needs of social expectation to maintain their legitimacy (De Villiers \& Van Staden, 2006).

Therefore, one of the advantages of this study is that it only focuses on climate change via the GHG emission problem, which eliminates the impact of other CSR issues.

Although EU ETS and CCA are legally binding, the disclosure of GHG emission performance and management remains voluntary and is at management's discretion. It is argued that climate change creates a legitimacy threat for companies (Pellegrino \& Lodhia, 2012).Companies have incentives to use disclosure to gain and maintain their legitimacy when facing exposures to the social and political processes through which social legitimacy is monitored and bestowed (Chauvey et al., 2015; Patten, 1992). The increase in GHG disclosure therefore indicates management's perception of a legitimacy gap and their use of GHG disclosure to respond to the increased expectation from society. GHG trading account holders are more responsive than non-GHG trading account holders. The disclosures of account holders are significantly better than those of non-account holders, while the improvement rate of GHG disclosure of non-account holders are higher than account holders. One of the possible explanations is that account holders have a better understanding of their GHG emission activities and more expertise in dealing with GHG emission information. Account holders work closely with the regulatory bodies, who in turn expect more disclosures from them. They already represent the best practice in GHG reporting and disclosures and therefore do not have the room to make further improvement. Nevertheless, when facing increased climate change concern - for example, after the introduction of EU ETS and CCA - account holders encounter increased expectation and make immediate responses to meet the expectations. The results in this study are consistent with prior evidence and in support of the notion that companies with more GHG emission exposure face greater social and political pressures and so use disclosures as a legitimacy tool to reduce these legitimacy threats.

Although GHG disclosures of the sample companies significantly improved during the period from 2004 to 2012, the quality of the disclosures remains low, especially with low levels of quantitative and monetary disclosures. The results are consistent with prior evidence, which suggests that the disclosures have been increasing across time, both in the number of companies making disclosures and in the amount of information being reported (Bebbington, Kirk, \& Larrinaga, 2012; Deegan \& Gordon, 1996), while the quality of the disclosures 
remains quite low (Bebbington et al., 2012; Chauvey et al., 2015). Some of the items in the disclosure index are even decreasing during the period. For example, the percentage of companies that disclose the amount they fund other organizations in GHG reduction research reduces to $8 \%$ in 2012 , while it peaks at $23 \%$ in 2007 . Some items in the index are paired in both qualitative and quantitative perspectives. For example, $88 \%$ of companies indicate their investment in energy efficiency and renewable energy, however only $28 \%$ disclose the real amount of investment they made. $64 \%$ of companies mention their investment in lower-GHG technology, while only $12 \%$ of companies quantify the amount of investment. The amount of quantitative disclosures in annual and standalone reports is much lower than that of qualitative disclosures, and the difference has become more significant during the last nine years, as analysed above. The results are consistent with what is found by (Chauvey et al., 2015). They argue that reporting appears to become the norm and seems to be more about legitimization than transparency, and this is caused by the lack of normativity of the new regulation.

\section{Conclusions, limitations and future research}

This paper investigates the longitudinal development of corporate GHG disclosures and how companies respond to the enactment of GHG reduction schemes. Our empirical results have shown that there is an overall increase in the quality of GHG disclosures during the period 2004-2012. However, this is a gradual change which is reflected in the achievement of a statistically significant increase of disclosures after the enactment of EU ETS and CCA. The results are consistent with prior social and environmental disclosure studies (Deegan et al., 2002; Gray et al., 1995; Hogner, 1982; Lodhia, 2011; Patten, 1992b) and resonate with the stratigic legitimacy perspective (Guthrie and Parker, 1989). But the mechanisms of the disclosure development seem to be complex. Further study of the disclosures between GHG trading account holders and non-account holders suggests that the former group disclose significantly more than the latter and are more responsive to the enactment of GHG reduction initiatives, while the disclosure improvement rate is lower than those of non-account holders, except after the enactment of the schemes.

It is concluded that the development of corporate GHG disclosure is a process of both legitimization and institutionalization. Companies mainly use social and environmental disclosures for legitimization rather than transparency, in response to social and political 
pressures from stakeholders. Companies tend to model themselves after those in a similar GHG-sensitive group that are perceived to be more legitimate and successful. This explains the continuously gradual improvement of corporate GHG emission disclosures. The enactments of EU ETS and CCA coerce the improvement of GHG disclosures, which would otherwise create significant threat to corporate legitimacy. The development of GHG disclosure also follows the normativity of CSR disclosure practice as suggested by (Bebbington et al., 2012)). Our study extends the previous studies of the normativity of mandatory reporting to voluntary reporting practices and argues that it may take longer for voluntary reporting to become normative, as corporates only respond to mandatory GHG reduction schemes through significant GHG disclosure improvement. Nevertheless, the quality of the disclosures remains low, especially with low levels of quantitative and monetary disclosures, and the GHG reporting at the moment seems to be more about legitimization than transparency. The results therefore justify the governmental intervention of corporate GHG disclosure.

This study contributes to the corporate GHG accounting and disclosure literature. It provides an overview of expected disclosures from government, lobby groups and other climate change related institutions by building up a comprehensive GHG disclosure index based on extant environmental and GHG disclosure literature and GHG reporting guidance and regulations. Our study also contributes to the understanding of current UK GHG disclosure practice; there is very limited research in this area (Freedman \& Jaggi, 2005). Furthermore, we shed light on the explanatory power of legitimacy theory by employing both longitudinal and statistical studies of corporate GHG disclosures. The findings have important implications for corporate top management and government, who are interested in improving corporate GHG reporting strategy and practice. 


\section{Reference}

Adams, C. A., Hill, W.-Y. and Roberts, C. B. (1998), "Corporate social reporting practices in Western Europe: legitimating corporate behaviour?", The British Accounting Review, Vol. 30 No. 1, pp. 1-21.

Aldrich, H. (1979), Organizations and environments, Prentice-Hall Englewood Cliffs, NJ.

Bebbington, J., Kirk, E. A. and Larrinaga, C. (2012), "The production of normativity: A comparison of reporting regimes in Spain and the UK", Accounting, Organizations and Society, Vol. 37 No. 2, pp. 78-94.

Bebbington, J., Larrinaga-González, C. and Moneva-Abadía, J. M. (2008), "Legitimating reputation/the reputation of legitimacy theory", Accounting, Auditing \& Accountability Journal, Vol. 21 No. 3, pp. 371-374.

Campbell, D. (2004), "A longitudinal and cross-sectional analysis of environmental disclosure in UK companies - a research note", The British Accounting Review, Vol. 36 No. 1, pp. 107-117.

CDP. (2012), "Carbon Action Report", available at: https://www.cdp.net/en/research/globalreports/carbon-action-report-2012 (accessed 20 February 2014).

Chauvey, J.-N., Giordano-Spring, S., Cho, C. H. and Patten, D. M. (2015), "The Normativity and Legitimacy of CSR Disclosure: Evidence from France", Journal of Business Ethics, Vol. 130 No. 4, pp. 1-15.

Chen, J. C. and Roberts, R. W. (2010), "Toward a more coherent understanding of the organization-society relationship: A theoretical consideration for social and environmental accounting research", Journal of Business Ethics, Vol. 97 No. 4, pp. 651-665.

Cho, C. H. and Patten, D. M. (2007), "The role of environmental disclosures as tools of legitimacy: A research note", Accounting, Organizations and Society, Vol. 32 No. 7, pp. 639-647.

Cook, A. (2009), "Emission rights: From costless activity to market operations", Accounting, Organizations and Society, Vol. 34 No. 3, pp. 456-468.

Cormier, D., Magnan, M. and Van Velthoven, B. (2005), "Environmental disclosure quality in large German companies: economic incentives, public pressures or institutional conditions?", European Accounting Review, Vol. 14 No. 1, pp. 3-39.

De Villiers, C. and Van Staden, C. J. (2006), "Can less environmental disclosure have a legitimising effect? Evidence from Africa", Accounting, Organizations and Society, Vol. 31 No. 8, pp. 763-781.

Deegan, C. (2002), "Introduction: The legitimising effect of social and environmental disclosures-a theoretical foundation", Accounting, Auditing \& Accountability Journal, Vol. 15 No. 3, pp. 282-311.

Deegan, C. and Gordon, B. (1996), "A study of the environmental disclosure practices of Australian corporations", Accounting and Business Research, Vol. 26 No. 3, pp. 187199.

Deegan, C., Rankin, M. and Tobin, J. (2002), "An examination of the corporate social and environmental disclosures of BHP from 1983-1997: A test of legitimacy theory", Accounting, Auditing \& Accountability Journal, Vol. 15 No. 3, pp. 312-343.

Deegan, C., Rankin, M. and Voght, P. (2000), "Firms' disclosure reactions to major social incidents: Australian evidence", Accounting Forum, Vol. 24 No. 1, pp. 101-130.

DiMaggio, P. J. and Powell, W. W. (1983), "The iron cage revisited: Institutional isomorphism and collective rationality in organizational fields", American Sociological Review, Vol. 48 No. 2, pp. 147-160. 
Dowling, J. and Pfeffer, J. (1975), "Organizational legitimacy: Social values and organizational behavior", Pacific Sociological Review, Vol. 18 No. 1, pp. 122-136.

Engels, A. (2009), "The European Emissions Trading Scheme: An exploratory study of how companies learn to account for carbon", Accounting, Organizations and Society, Vol. 34 No. 3, pp. 488-498.

European Commission. (2015), "The EU Emissions Trading System (EU ETS)", available at: http://ec.europa.eu/clima/policies/ets/index en.htm (accessed December 12 2015).

Freedman, M. and Jaggi, B. (2005), "Global warming, commitment to the Kyoto protocol, and accounting disclosures by the largest global public firms from polluting industries", The International Journal of Accounting, Vol. 40 No. 3, pp. 215-232.

Gray, R., Kouhy, R. and Lavers, S. (1995), "Corporate social and environmental reporting: a review of the literature and a longitudinal study of UK disclosure", Accounting, Auditing \& Accountability Journal, Vol. 8 No. 2, pp. 47-77.

Guthrie, J. and Parker, L. D. (1989), "Corporate social reporting: a rebuttal of legitimacy theory", Accounting and Business Research, Vol. 19 No. 76, pp. 343-352.

Hall, R. H. (1977), Organizations, Prentice-Hall New Jersey.

Hopwood, A. G. (2009), "Accounting and the environment", Accounting, Organizations and Society, Vol. 34 No. 3, pp. 433-439.

Kim, E.-H. and Lyon, T. (2011), "When does institutional investor activism increase shareholder value?: the carbon disclosure project", The BE Journal of Economic Analysis \& Policy, Vol. 11 No. 1, pp. 23-50.

Kolk, A., Levy, D. and Pinkse, J. (2008), "Corporate responses in an emerging climate regime: the institutionalization and commensuration of carbon disclosure", European Accounting Review, Vol. 17 No. 4, pp. 719-745.

Liao, L., Luo, L. and Tang, Q. (2014), "Gender diversity, board independence, environmental committee and greenhouse gas disclosure", The British Accounting Review, Vol. 47 No. 4, pp. 409-424.

Lohmann, L. (2009), "Toward a different debate in environmental accounting: The cases of carbon and cost-benefit", Accounting, Organizations and Society, Vol. 34 No. 3, pp. 499-534.

Mahadeo, J. D., Oogarah-Hanuman, V. and Soobaroyen, T. (2011), "A longitudinal study of corporate social disclosures in a developing economy", Journal of Business Ethics, Vol. 104 No. 4, pp. 545-558.

Matisoff, D. C., Noonan, D. S. and O'Brien, J. J. (2013), "Convergence in environmental reporting: assessing the Carbon Disclosure Project", Business Strategy and the Environment, Vol. 22 No. 5, pp. 285-305.

Meyer, J. W. and Rowan, B. (1977), "Institutionalized organizations: Formal structure as myth and ceremony", American Journal of Sociology, Vol. 83 No. 2, pp. 340-363.

Mohamed, C., Sylvain, D. and Jacques, R. (2014), "France's new economic regulations: Insights from institutional legitimacy theory", Accounting, Auditing \& Accountability Journal, Vol. 27 No. 2, pp. 283 - 316.

O'Donovan, G. (2002), "Environmental disclosures in the annual report: extending the applicability and predictive power of legitimacy theory", Accounting, Auditing \& Accountability Journal, Vol. 15 No. 3, pp. 344-371.

Oliveira, M. C., Junior, J. É. P. and Oliveira, O. V. (2014), "Corporate social reporting practices of French and Brazilian Companies: a comparison based on institutional theory", Revista de Contabilidade e Organizações, Vol. 7 No. 18, pp. 60-73.

Patten, D. M. (1992), "Intra-industry environmental disclosures in response to the Alaskan oil spill: a note on legitimacy theory", Accounting, Organizations and Society, Vol. 17 No. 5, pp. 471-475. 
Pellegrino, C. and Lodhia, S. (2012), "Climate change accounting and the Australian mining industry: exploring the links between corporate disclosure and the generation of legitimacy", Journal of Cleaner Production, Vol. 36 No. 11, pp. 68-82.

Peng, J., Sun, J. and Luo, R. (2015), "Corporate Voluntary Carbon Information Disclosure: Evidence from China's Listed Companies", The World Economy, Vol. 38 No. 1, pp. 91-109.

Scott, W. R., Ruef, M., Mendel, P. J. and Caronna, C. A. (2000), Institutional change and healthcare organizations: From professional dominance to managed care, University of Chicago Press, London.

Stanny, E. (2013), "Voluntary disclosures of emissions by US firms", Business Strategy and the Environment, Vol. 22 No. 3, pp. 145-158.

Tauringana, V. and Chithambo, L. (2014), "The effect of DEFRA guidance on greenhouse gas disclosure", The British Accounting Review, Vol. 47 No. 4, pp. 425-444.

Wiseman, J. (1982), "An evaluation of environmental disclosures made in corporate annual reports", Accounting, Organizations and Society, Vol. 7 No. 1, pp. 53-63.

Zucker, L. G. (1977), "The role of institutionalization in cultural persistence", American Sociological Review, Vol. 42 No. 5, pp. 726-743. 